Article

\title{
Isoliquiritigen Enhances the Antitumour Activity and Decreases the Genotoxic Effect of Cyclophosphamide
}

\author{
Hong Zhao ${ }^{1, \dagger}$, Xuan Yuan ${ }^{2, \dagger}$, Defang Li ${ }^{1}$, Hongmei Chen ${ }^{1}$, Jiangtao Jiang ${ }^{1}$, Zhiping Wang ${ }^{2}$,
} Xiling Sun ${ }^{3, *}$ and Qiusheng Zheng ${ }^{1,4, *}$

1 School of Pharmacy, Shihezi University, Shihezi 832002, China

2 Lanzhou University Second Hospital, Lanzhou University, Lanzhou 730000, China

3 School of integrated traditional Chinese and Western Medicine, Binzhou Medical College, Yantai 264000, China

4 Life Science School, Yantai University, Yantai 264000, China

$\dagger$ These authors contributed equally to this work.

* Authors to whom correspondence should be addressed; E-Mails: sunxiling@sohu.com (X.S.); zqsyt@sohu.com (Q.Z).

Received: 3 May 2013; in revised form: 16 July 2013 / Accepted: 22 July 2013 /

Published: 24 July 2013

\begin{abstract}
The aim of this study was to evaluate the antitumour activities and genotoxic effects of isoliquiritigenin (ISL) combined with cyclophosphamide (CP) in vitro and in vivo. U14 cells were treated with either of ISL $(5-25 \mu \mathrm{g} / \mathrm{mL})$ or CP $(0.25-1.25 \mathrm{mg} / \mathrm{mL})$ alone or with combination of ISL $(5-25 \mu \mathrm{g} / \mathrm{mL})$ and CP $(1.0 \mathrm{mg} / \mathrm{mL})$ for $48 \mathrm{~h}$. The proliferation inhibitory effect in vitro was evaluated by MTT and colony formation assays. KM mice bearing U14 mouse cervical cancer cells were used to estimate the antitumour activity in vivo. The genotoxic activity in bone marrow polychromatic erythrocytes was assayed by frequency of micronuclei. The DNA damage in peripheral white blood cells was assayed by single cell gel electrophoresis. The results showed that ISL enhanced antitumour activity of $\mathrm{CP}$ in vitro and in vivo, and decreased the micronucleus formation in polychromatic erythrocytes and DNA strand breaks in white blood cells in a dose-dependent way.
\end{abstract}

Keywords: isoliquiritigenin; antitumour; cyclophosphamide; genotoxic effect 


\section{Introduction}

Cancer is one of the major causes of mortality in humans throughout the World. According to a report dealing with the incidence and mortality of cancer in the World, about 12.7 million cancer cases and 7.6 million cancer deaths were estimated to have occurred in 2008; of these, $56 \%$ of the cases and $64 \%$ of the deaths occurred in the economically developing world [1]. In China, cancer has become the leading cause of deaths among urban and rural residents. The high rate of malignancy of these neoplasms is associated with rapid proliferation, numerous early metastases and high resistance to conventional treatments involving surgery, chemotherapy and radiation. Although preventive measures like chemotherapy are very useful, these often result in manifestation of chronic side effects [2,3]. Cyclophosphamide (CP), also known as cytophosphane, is a nitrogen mustard alkylating agent. It has been used to treat leukemia [4], breast cancer [5], small cell lung cancer [6], cervical cancer [7], non-Hodgkin's lymphoma [8] and so on. However, it has severe and life-threatening adverse effects. Some reports indicated that CP could cause temporary or (more rarely) permanent sterility [9] and produce chromosome damage [10], micronuclei [11], sister chromatid exchanges and DNA strand breaks in many kinds of mouse cells [12]. Therefore, it is desirable to find a compound that can decrease the genotoxic effects of cyclophosphamide without having any negative effect on its antitumour activity.

Licorice (Glycyrrhiza uralensis) has been used for more than four millennia as a flavoring agent in foods, beverages, and tobacco, and to treat individuals with gastric or duodenal ulcers [13], sore throats, coughs, bronchitis, arthritis [14], and allergies [15]. Moreover, many studies have revealed that several licorice derived compounds, i.e., glycyrrhizin, isoliquiritigenin (ISL, Figure 1), licochalcone, and glabridin, have a variety of pharmaceutical effects [16-19]. In addition, ISL, a dietary flavonoid, has been evaluated in terms of its antioxidative effects [20], antiplatelet aggregation effects [21], and estrogenic properties [22]. In particular, ISL can suppress proliferation and induce apoptosis in many kinds of cancer cells, including human promyelocytic cell line [23], human glioma cells [24], human uterine leiomyoma cells [25], colon cancer cells [26], human prostate cancer [27], and human hepatoma cells [28]. ISL also suppresses migration and invasion in human breast cancer cells [29] and mouse renal cell carcinoma [30]. The results from our lab showed that ISL was able to induce monocytic differentiation in HL-60 human leukemia cells [31,32] or B16F0 mouse melanoma cells [33], suppress proliferation and induce apoptosis in HeLa human cervical carcinoma cells [34,35] and SKOV-3 human ovarian carcinoma cells [36], we also found that ISL and CP have synergistic action in inhibition of proliferation of U14 cells [37]. However, useful information about the pharmacological and genotoxic effects of ISL combined with chemotherapeutic agents is scarce. In this study, the effects of ISL on the antitumour acitivity and genotoxic effect of CP were investigated.

Figure 1. The chemical structure of ISL.

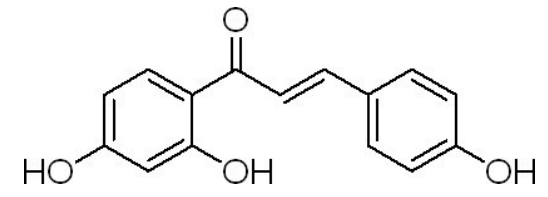




\section{Results and Discussion}

\subsection{High Concentration of ISL Significantly Enhances CP-Induced Inhibition of U14 Cells Proliferation in Vitro}

As shown in Figure 2, after treatment by $\mathrm{CP}(0,0.25,0.5,0.75,1.0,1.25 \mathrm{mg} / \mathrm{mL})$ or ISL $(5,10,15$, 20 and $25 \mu \mathrm{g} / \mathrm{mL}$ ), respectively, for $48 \mathrm{~h}$, a significant concentration-dependent reduction in cell viability was observed, the proliferation rate of $1.25 \mathrm{mg} / \mathrm{mL}$ CP-treated U14 cells decreased by $68.68 \%, 25 \mu \mathrm{g} / \mathrm{mL}$ ISL decreased by $61.57 \%$. In view of the significant proliferation inhibition of U14 cells induced by $\mathrm{CP}$, we chose the concentration of $1.0 \mathrm{mg} / \mathrm{mL}$ for the subsequent in vitro assays. The inhibition rate of co-treatment with $1.0 \mathrm{mg} / \mathrm{mL} \mathrm{CP}$ and low concentration of ISL $(5,10,15 \mu \mathrm{g} / \mathrm{mL})$ is lower than that of $1.0 \mathrm{mg} / \mathrm{mL} \mathrm{CP}$ alone, however the combination of ISL $(20 \mu \mathrm{g} / \mathrm{mL})$ significantly enhances CP-induced inhibition of U14 cells proliferation, the percentage of viable cells decreased from $47.00 \%$ (after treatment with CP $1.0 \mathrm{mg} / \mathrm{mL}$ ) to $27.64 \%$ (treatment with the combination of $1.0 \mathrm{mg} / \mathrm{mL} \mathrm{CP}$ and $20 \mu \mathrm{g} / \mathrm{mL}$ ISL). To further confirm the potentiation of co-treatment, the optimal combination of ISL $20 \mu \mathrm{g} / \mathrm{mL}$ and CP $1.0 \mathrm{mg} / \mathrm{mL}$ was used to investigate the effect on suppression of long-term colony formation. Exposure of U14 with ISL $(20 \mu \mathrm{g} / \mathrm{mL})$ and CP $(1.0 \mathrm{mg} / \mathrm{mL})$ resulted in a greater inhibition of colony formation than each agent alone (Figure 3), the colony-forming rate of cells exposed to ISL and CP was decreased by $70.64 \%$ compared with the control and $25.41 \%$ compared with CP alone.

Figure 2. Effects of ISL, CP alone or their combination (ISL + CP) on U14 cells proliferation. (A) The inhibition rate on cell proliferation after $48 \mathrm{~h}$ treatment with $\mathrm{CP}$ $(0,0.25,0.5,0.75,1.0,1.25 \mathrm{mg} / \mathrm{mL})$ alone; $(\mathbf{B})$ The inhibition rate on cell proliferation after $48 \mathrm{~h}$ treatment with ISL $(5,10,15,20$ and $25 \mu \mathrm{g} / \mathrm{mL})$ alone or ISL $(5,10,15,20$ and $25 \mu \mathrm{g} / \mathrm{mL})$ co-treatment with $\mathrm{CP}(1.0 \mathrm{mg} / \mathrm{mL})$. Data are presented as mean \pm S.D. from three independent experiments. $* * p<0.01 ; * p<0.05$ versus control group.
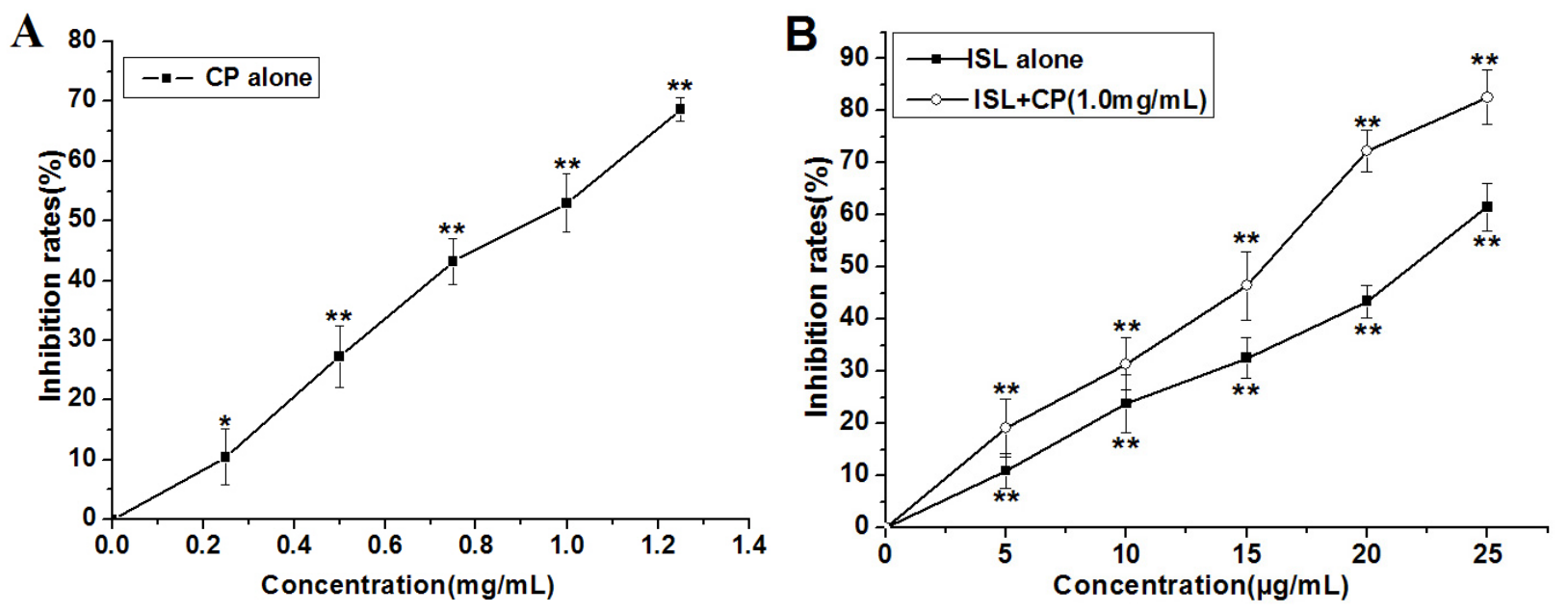

\subsection{Co-Treatment with ISL and CP Synergestically Decreases the Tumour Growth in Vivo}

To further explore the possible synergistic effects of ISL with conventional chemotherapeutic drug, $\mathrm{CP}$, mouse cervical cancer U14 cells were transplanted subcutaneously into KM mice. As shown in 
Figure 4, co-treatment with ISL $(20 \mathrm{mg} / \mathrm{kg})$ and CP $(40 \mathrm{mg} / \mathrm{kg})$ significantly inhibited the growth of cervical cancer U14 cells, the inhibition rate reached $65.66 \%$, while the inhibition rate was $43.55 \%$ and $35.57 \%$ when treated with ISL $(20 \mathrm{mg} / \mathrm{kg})$ or CP $(40 \mathrm{mg} / \mathrm{kg})$ alone respectively (Figure 4).

Figure 3. Effects of ISL, CP alone or their combination (ISL + CP) on the clonogenic potential in U14 cells. U14 cells were treated with ISL $(20 \mu \mathrm{g} / \mathrm{mL})$ or CP $(1.0 \mathrm{mg} / \mathrm{mL})$ alone or with their combination and allowed to proliferate for eight days. (A) Representative images of colony forming assays. (B) Colonies were counted and expressed as a percent of the control. Data are presented as mean \pm S.D. from three independent experiments. $* * p<0.01$ versus control group; ${ }^{\#} p<0.05$ versus $\mathrm{CP}$-treated group.
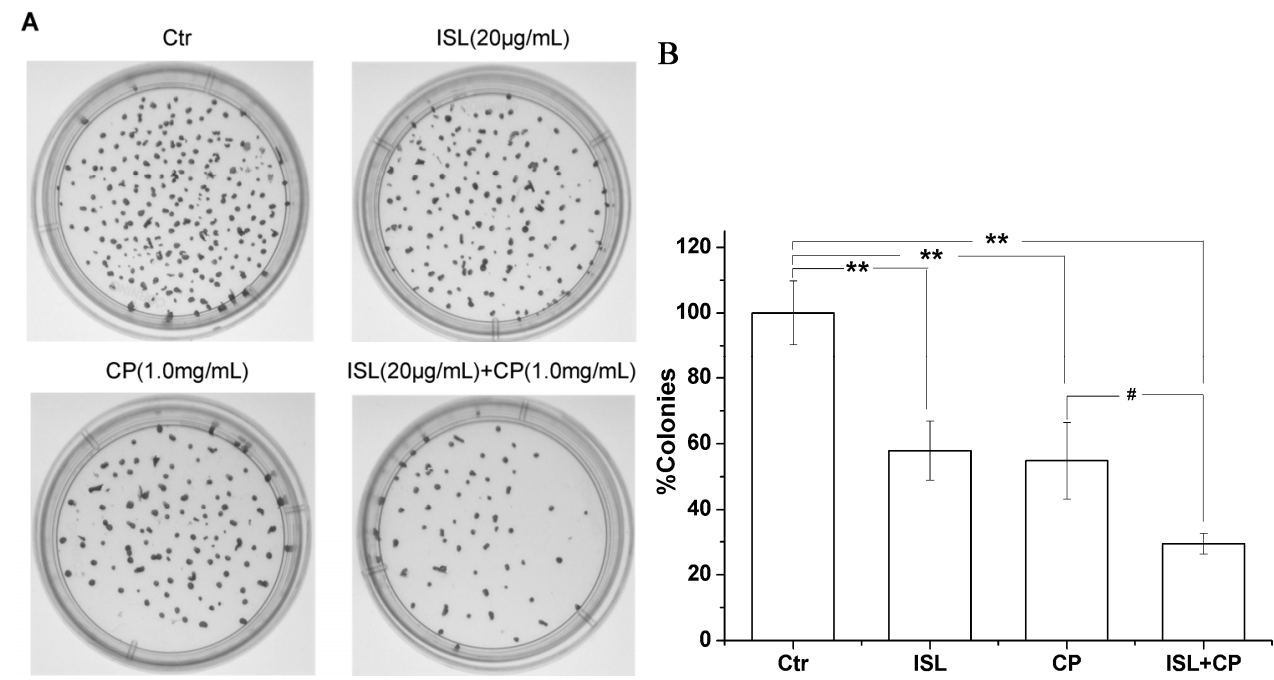

Figure 4. Synergestic inhibition of ISL and $\mathrm{CP}$ on tumour growth in vivo. KM mice bearing cervical cancer U14 cells were administrated with ISL $(5 \sim 20 \mathrm{mg} / \mathrm{kg}$, orally administered once a day for 10 consecutive days) or $\mathrm{CP}(40 \mathrm{mg} / \mathrm{kg}$, injected by intraperitoneally a single dose of $40 \mathrm{mg} / \mathrm{kg}$ body weight at the first day). The implanted sarcomas were separated and weighed on day 11. (A) Images of the tumour morphology. (B) The quantitative results of tumor growth-inhibition. Data are presented as mean \pm S.D. from 10 individual treatments. ${ }^{*} p<0.05$; ${ }^{* *} p<0.01$ versus control group; ${ }^{*} p<0.05$; \# $p<0.01$ versus CP-treated group.

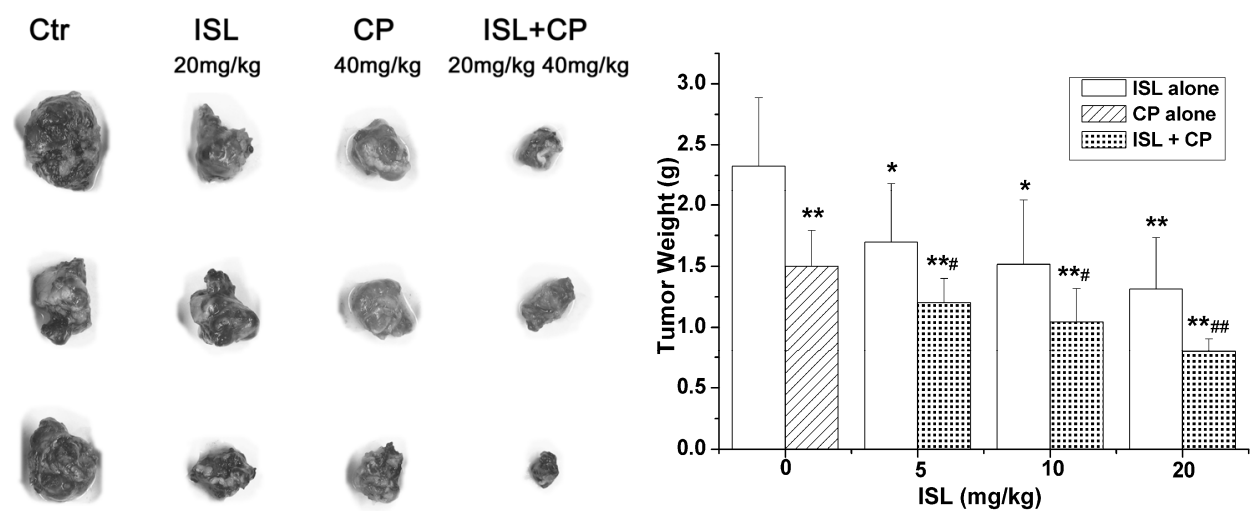




\subsection{ISL Inhibits the Micronuclei Yield Induced by $C P$}

$\mathrm{CP}$ alone significantly increases micronucleus formation in polychromatic erythrocytes (Figure 5), approximately 11 times higher than that of control group, while ISL alone has no influence on micronuclei. Pretreatment with ISL partially blocked CP-induced micronuclei in a dose-dependent way. The inhibition rate of ISL ( $20 \mathrm{mg} / \mathrm{kg}$ ) treatment on micronuclei reached $41.4 \%$ (Figure 5).

Figure 5. Pretreatment with ISL inhibits CP-induced micronucleus formation. Mice were pretreated with ISL $(5,10,20 \mathrm{mg} / \mathrm{kg})$ before CP treatment for three consecutive days. After $\mathrm{CP}$ (a single dose of $40 \mathrm{mg} / \mathrm{Kg}$ ) treatment, mice were sacrificed after $24 \mathrm{~h}$ and the femoral bone marrow cells were collected. Smear slides of bone marrow cells were stained with AO. (A) Representative images of micronucleus formation assays. (B) The micronuclei (MN) in 1,000 polychromatic erythrocytes (PCEs) were counted under a fluorescence Carl Zeiss microscope. Data are presented as mean \pm S.D. from 10 individual treatments; $* p<0.05, * * p<0.01$ versus $\mathrm{CP}$-treated group.
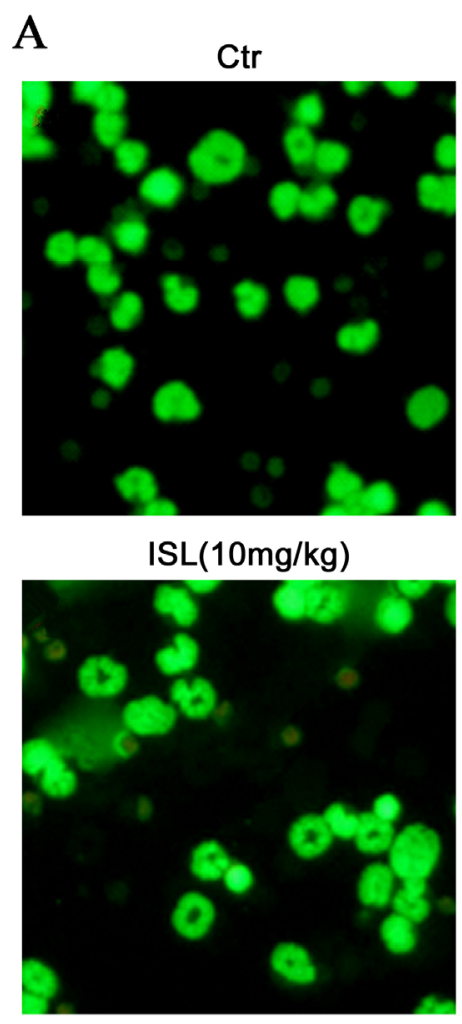
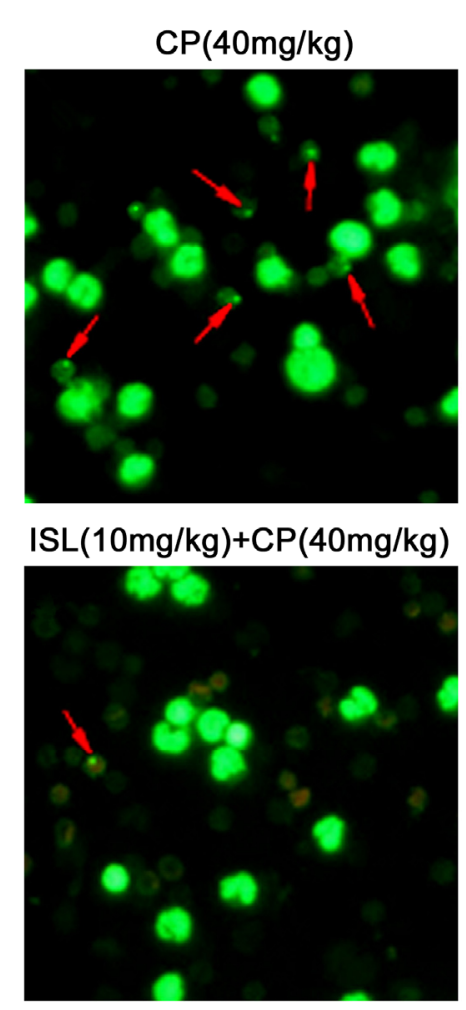

B

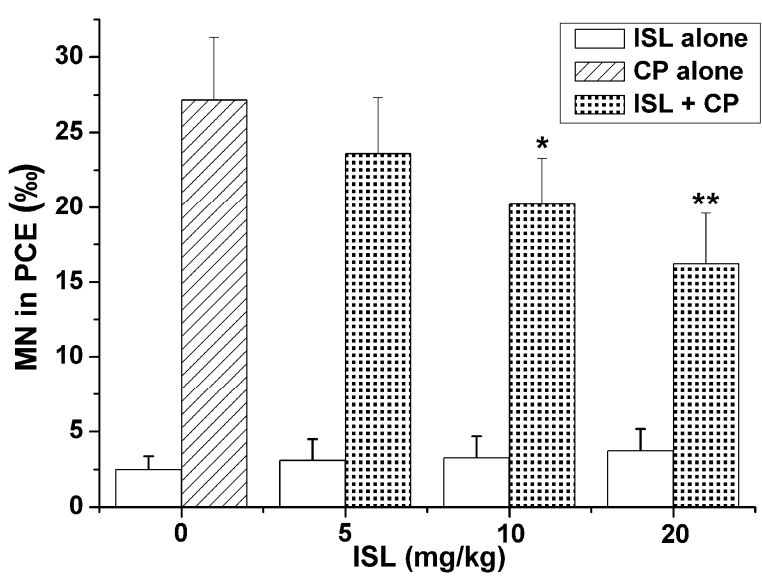

\subsection{ISL Inhibits the DNA Damage Induced by $C P$}

As shown in Figure 6, CP alone significantly increased the DNA damage detected by SCGE, as shown by the significant increase of olive tail moment; ISL alone had no influence on DNA, and when co-treated with combination of ISL and CP, the olive tail moment decreased in a dose-dependent manner (Figure 6). 
Figure 6. Pretreatment with ISL inhibits CP-induced DNA-damage. Mice were pretreated with ISL $(5,10,20 \mathrm{mg} / \mathrm{Kg}$ ) before $\mathrm{CP}$ treatment for 3 consecutive days. After CP (a single dose of $40 \mathrm{mg} / \mathrm{Kg}$ ) treatment for $24 \mathrm{~h}$, blood was obtained from murine tail tips. Comet assay was performed as described in Materials and Methods. (A) Representative images of Comet assay. (B) The tail moment was measured by CASP software. The mean value of the tail moment in a particular sample was taken as an index of DNA damage in this sample. Data are presented as mean \pm S.D. from 10 individual treatments. $* p<0.05$, $* * p<0.01$ versus $\mathrm{CP}$-treated group.

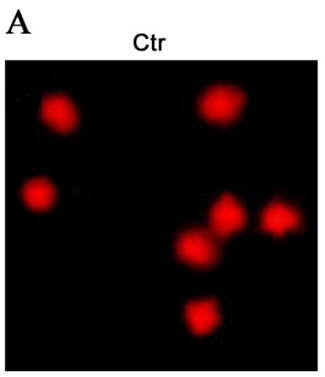

ISL(10 mg/kg)

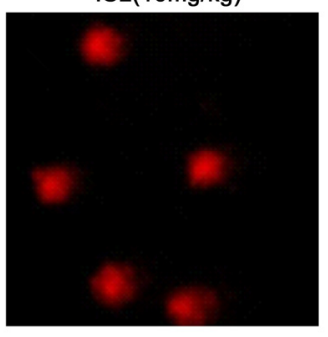

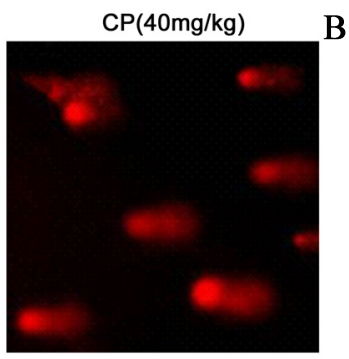

$\mathrm{ISL}(10 \mathrm{mg} / \mathrm{kg})+\mathrm{CP}(40 \mathrm{mg} / \mathrm{kg})$

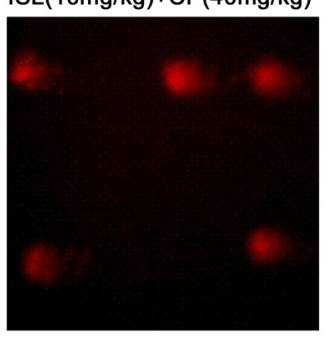

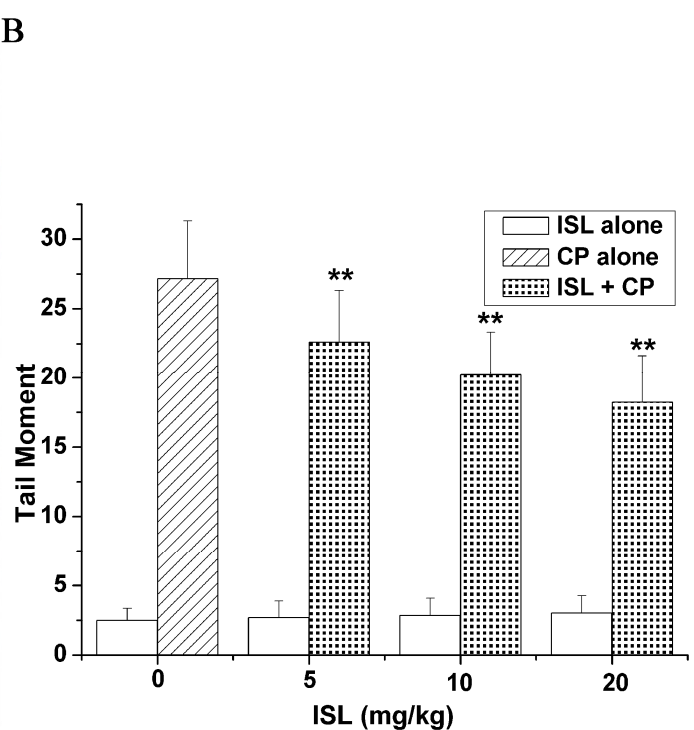

\subsection{Discussion}

Improvements in the therapy of malignant disease during the past two decades have allowed long-term survival and cure in many patients. However, in recent years secondary malignancies have been increasingly recognized as an important late complication after chemo- and radiotherapy [38,39]. Some reports indicate that a few secondary malignant cases are related to cyclophosphamide (CP) [40-42] and that CP could induce the formation of urinary bladder tumours in rats [43], while still being used extensively for its efficacy on primary tumours, as the first-line chemotherapy agent against breast cancer, small cell lung cancer, cervical cancer and non-Hodgkin's lymphoma. It has been shown that $\mathrm{CP}$ could produce chromosome damage, micronuclei, sister chromatid exchanges and DNA strand breaks in many kinds of mouse cells $[10,44,45]$. It is obvious that all above indices are related with carcinogenesis. Therefore, it is necessary to find a compound that can decrease the genotoxic effects of $\mathrm{CP}$ without having any negative effect on its antitumour activity.

ISL, a dietary flavonoid, exhibits antitumor activities, including the capability to suppresses proliferation and induce apoptosis in human cervical carcinoma cells [35], to suppresses migration and invasion of human breast cancer cells [29], and to induce monocytic differentiation in HL-60 cells [31]. Previous studies indicated that flavonoids may protect the cells from toxicity induced by CP [46]. ISL has been found to counteract the side effects of cisplatin therapy in cancer patients [47] or to reduce pulmonary metastasis, without any weight loss or leukocytopenia [30]. However, limited information is available concerning the antitumour activity and genotoxic effects of ISL combined with CP. In this study, 
the antitumour activity and genotoxic effect of ISL combined with intraperitoneal injection of cyclophosphamide was investigated. A novel finding obtained from this study is that a combination of ISL and CP significantly inhibited the U14 tumour growth in vitro and in vivo, and the inhibition ratio reached $82.61 \%$ and $65.66 \%$ respectively. More important, ISL partially decreased CP-induced micronuclei formation, and dose-dependently $(5,10,20 \mathrm{mg} / \mathrm{kg})$ inhibited CP-induced DNA strand breaks, making ISL may be a candidate to decrease the genotoxic effects of chemotherapy with CP.

\section{Experimental}

\subsection{Materials}

Isoliquiritigenin (ISL, purity $\geq 98 \%$ ) was purchased from Jiangxi Herb Tiangong Technology Co., Ltd. (Nanchang, China). Cyclophosphamide (CP) was purchased from Jiangsu Hengrui Medicine Co., Ltd. (Lianyungang, China). Ethidium bromide, acridine orange and Triton X-100 were purchased from Sigma Chemical Co. (St. Louis, MO, USA). Low melting point (LMP) agarose and normal agarose (electrophoresis grade) were obtained from Gibco-BRL (Grand Island, NY, USA). Heparin sodium was bought from Roche (Sao Paulo, SP, Brazil) under the commercial name Liquemine.

\subsection{Animal Preparation}

SPF KM female mice, aged 5-7 weeks and weighed from 18 to $22 \mathrm{~g}$, were obtained from the Institute of Laboratory Animal Science, Chinese Academy of Medical Sciences, Beijing, China. The mice were acclimatized to laboratory conditions $\left(22 \pm 3{ }^{\circ} \mathrm{C}\right.$ and $60 \%$ humidity) for 7 days, with a commercial standard mouse cube diet (Shihezi University Laboratory Animal Center, Xinjiang, China) and water ad libitum. After acclimatization, the mice were randomly divided into control and treated groups.

\subsection{Cell Culture}

Mouse cervical cancer U14 cells were obtained from China Center for Type Culture Collection (CCTCC), Wuhan, China. The cells were maintained in RPMI 1640 supplemented with 10\% FBS, $100 \mathrm{U} / \mathrm{mL}$ penicillin, and $100 \mu \mathrm{g} / \mathrm{mL}$ streptomycin at $37^{\circ} \mathrm{C}$ with $5 \% \mathrm{CO}_{2}$. Cells were split every three days and were diluted one day before each experiment.

\subsection{Cell Viability Assay}

Cell viability was measured via 3-(4,5-dimethylthiazol-2-yl)-2,5-diphenyltetrazolium bromide (MTT) assay [48]. Cells were washed with fresh media, cultured in 96-well plates (Nunc, Roskilde, Denmark) at $1 \times 10^{5}$ cells $/ \mathrm{mL}$, and then incubated with CP $(0,0.25,0.5,0.75,1.0,1.25 \mathrm{mg} / \mathrm{mL})$ or ISL $(0,5,10,15,20$ and $25 \mu \mathrm{g} / \mathrm{mL})$ or their combination for $48 \mathrm{~h}$. The medium was aspirated after incubation, and then fresh medium containing $10 \mu \mathrm{L}$ of $5 \mathrm{mg} / \mathrm{mL}$ MTT was added. The medium was removed after $4 \mathrm{~h}$ and replaced with blue formazan crystal dissolved in $150 \mu \mathrm{L}$ DMSO. Absorbance at $490 \mathrm{~nm}$ was measured using a fluorescent plate reader (Millipore Bedford, MA, USA). Data were 
expressed as the percentage of cell viability compared with the control (DMSO). The inhibition rate was quantified using the following formula:

$$
\text { Inhibition } \quad \text { rate }=\left(1-\frac{\mathrm{OD} \text { of } \text { sample }}{\mathrm{OD} \text { of control }}\right)
$$

\subsection{Colony Formation Assay}

For this assay, cells were seeded at 500 cells per $100 \mathrm{~mm}$ culture dish and allowed to attach overnight [49]. The cells were treated with ISL $(20 \mu \mathrm{g} / \mathrm{mL}), \mathrm{CP}(1.0 \mathrm{mg} / \mathrm{mL})$ or their combination and maintained under standard cell culture conditions at $37{ }^{\circ} \mathrm{C}$ and $5 \% \mathrm{CO}_{2}$ in a humid environment. After 8 days, the dishes were washed twice in PBS, fixed with methanol, stained with Giemsa dye (Sigma), washed with PBS and air dried. Colonies exhibiting a minimum of 50 viable cells were counted. Colony plating efficiency was calculated to be the number of viable plated cells, and was expressed as a percentage of inoculated cells. The percent of colonies was calculated using the number of colonies formed in treatment divided by number of colonies formed in control group.

\subsection{In Vivo Antitumour Activity Assay}

KM mice were implanted subcutaneously with $0.2 \mathrm{~mL}\left(1 \times 10^{7} \mathrm{~mL}\right.$ in sodium chloride $)$ U14 cells. After implantation for $24 \mathrm{~h}$, mice bearing U14 were randomly assigned to eight groups (each group consisted of 10 mice) as follows: (1) control, (2) $40 \mathrm{mg} / \mathrm{kg} \mathrm{CP}$ alone, (3) $5 \mathrm{mg} / \mathrm{kg} \mathrm{ISL}$, (4) $10 \mathrm{mg} / \mathrm{kg}$ ISL, (5) $20 \mathrm{mg} / \mathrm{kg}$ ISL, (6) $5 \mathrm{mg} / \mathrm{kg}$ ISL combined with $40 \mathrm{mg} / \mathrm{kg} \mathrm{CP}$, (7) $10 \mathrm{mg} / \mathrm{kg}$ ISL combined with $40 \mathrm{mg} / \mathrm{kg} \mathrm{CP}$ and (8) $20 \mathrm{mg} / \mathrm{kg}$ ISL combined with $40 \mathrm{mg} / \mathrm{kg} \mathrm{CP}$. ISL, suspended in $0.5 \%$ carboxymethyl cellulose sodium (CMC-Na), was orally administered once a day for 10 consecutive days. CP, dissolved in saline, was injected intraperitoneally as a single dose of $40 \mathrm{mg} / \mathrm{kg}$ body weight at the first day. Controls received the vehicle alone $(20 \mathrm{~mL} / \mathrm{kg})$. Mice were sacrificed by cervical dislocation on day 11. Implanted sarcomas were separated and weighed, then the tumor inhibition rate (TIR) was calculated according to the following formulate: TIR $(\%)=(\mathrm{WC}-\mathrm{WE}) / \mathrm{WE} \times 100 \%$. WC: Mean tumor weight in Group 1 (control group); WE: Mean tumor weight in Group 2-8 (tested groups) respectively; $>30 \%$ was regarded as having inhibitory effect.

\subsection{Micronucleus Formation Assay}

After acclimation, eighty female mice were randomly assigned to the eight groups as above mentioned. ISL was administered orally for three consecutive days. After the last administration, a single dose of CP $40 \mathrm{mg} / \mathrm{kg}$ body weight was injected intraperitoneally while the vehicle alone $(20 \mathrm{~mL} / \mathrm{kg}$ ) was injected as the control. Blood (about $50 \mu \mathrm{L}$ ) was obtained $24 \mathrm{~h}$ after $\mathrm{CP}$ treatment from murine tail tips by a small incision and immediately mixed with heparin sodium $(20 \mu \mathrm{L})$. The animals were then sacrificed by cervical dislocation. Bone marrow smears and staining were done following the procedure described by Tinwell [50]. Femoral bone marrow was flushed out by using 1\% sodium citrate solution at $37{ }^{\circ} \mathrm{C}$. The marrow was homogenized and centrifuged at $1,000 \mathrm{~g}$ for $5 \mathrm{~min}$. The supernatant was decanted and the pellet was homogenized with the residual fluid and add $2 \mathrm{~mL}$ PBS buffer. After harvesting and washing, cells were stained with $50 \mu \mathrm{g} / \mathrm{mL}$ acridine orange and visualized 
with a Carl Zeiss fluorescence microscope with the corresponding filters (470-490 nm excitation and $515 \mathrm{~nm}$ emission wavelengths). For each animal, 1,000 polychromatic erythrocytes were examined by utilizing a number of fields, and the number of micronucleated polychromatic erythrocytes was recorded. Every individual experiment was performed in triplicate.

\subsection{Comet Assay}

The alkaline version of the comet assay (single cell gel electrophoresis, SCGE) was performed according to the protocol developed by Wang et al. [51]. Blood cells/heparin mixtures $(7 \mu \mathrm{L})$ were embedded in LMP agarose $(93 \mu \mathrm{L}, 0.75 \mathrm{~g} / 100 \mathrm{~mL}$ PBS $)$ and the resulting mixture was spread over a precoated microscope slide $(1.5 \mathrm{~g} / 100 \mathrm{~mL}$ agarose). A cover glass was then gently placed over the slide and put at $4{ }^{\circ} \mathrm{C}$ for $5 \mathrm{~min}$ to allow gel solidification. After removal of the coverslips, the cells were lysed at $4{ }^{\circ} \mathrm{C}$ for at least one $\mathrm{h}$ in a freshly prepared, ice-cold solution of $2.5 \mathrm{M} \mathrm{NaCl}, 100 \mathrm{mM}$ Na2EDTA, $10 \mathrm{mM}$ Trizma Base, 1\% Na-lauryl sarcosinate, $\mathrm{pH}$ 10, and 1\% Triton X-100, and 10\% fresh DMSO added. Shortly after lysis, the slides were placed on a horizontal electrophoresis unit. Then they were exposed to alkali $(300 \mathrm{mM} \mathrm{NaOH}, 1 \mathrm{mM} \mathrm{Na} 2 \mathrm{EDTA}, \mathrm{pH} \pm 13)$ at $4{ }^{\circ} \mathrm{C}$ for $20 \mathrm{~min}$, to allow DNA unwinding. Electrophoresis was performed at $300 \mathrm{~mA}$ and $25 \mathrm{~V}(0.90 \mathrm{~V} / \mathrm{cm})$ at $4{ }^{\circ} \mathrm{C}$ for 15 min. The slides were then neutralized (Tris $0.4 \mathrm{M}, \mathrm{pH} 7.5$ ), stained with ethidium bromide $(20 \mathrm{mg} / \mathrm{mL})$, and were observed and photographed at $400 \times$ magnification using a Carl Zeiss reverse fluorescence microscope equipped with an excitation filter (BP 546/12 nm) and a barrier filter $(590 \mathrm{~nm})$. The DNA damage degree was assessed with CASP, a free SCGE analysis system published by Konca et al. [52]. The images of one hundred cells were randomly selected from each slide and the tail moment was measured. The tail moment is positively correlated with the level of DNA breakage in a cell. The mean value of the tail moment in a particular sample was taken as an index of DNA damage in this sample.

\subsection{Statistical Analysis}

The results were expressed as mean \pm S.D. and analyzed by one-way analysis of variance (ANOVA). The values with $p<0.05$ were considered as statistically significant. The analyses were carried out using the Origin 8.0 software (Origin Lab Corporation, Northampton, MA, USA).

\section{Conclusions}

In conclusion, our studies indicated that ISL significantly inhibits the genotoxic effects induced by $\mathrm{CP}$, and enhances the antitumor activity of $\mathrm{CP}$ both in vitro and in vivo. Therefore, ISL, is a powerful candidate drug, to decrease the toxic effects and to enhance the therapeutic effects of the chemotherapy with cyclophosphamide.

\section{Acknowledgments}

This study was supported by the National Natural Science Foundation of China (No. 81260338), The Xinjiang Production and Construction Corps Fund for Distinguished Young Scientists 
(2011CD006), and International Cooperation Project 2012BC001 and Major State Basic Research Development Program (2010CB535003) grants to Q.S. Zheng.

\section{Conflict of Interest}

The authors declare no conflict of interest.

\section{References}

1. Jemal, A.; Bray, F.; Center, M.M.; Ferlay, J.; Ward, E.; Forman, D. Global cancer statistics. CA Cancer J. Clin. 2011, 61, 69-90.

2. Attar, E.C.; Ervin, T.; Janicek, M.; Deykin, A.; Godleski, J. Side effects of chemotherapy. Case 3. Acute interstitial pneumonitis related to gemcitabine. J. Clin. Oncol. 2000, 18, 697-698.

3. Kerbel, R.S.; Kamen, B.A. The anti-angiogenic basis of metronomic chemotherapy. Nat. Rev. Cancer 2004, 4, 423-436.

4. Hanafelt, T.D.; Lin, T.; Geyer, S.M.; Zent, C.S.; Leung, N.; Kabat, B.; Bowen, D.; Grever, M.R.; Byrd, J.C.; Kay, N.E. Pentostatin, cyclophosphamide, and rituximab regimen in older patients with chronic lymphocytic leukemia. Cancer 2007, 109, 2291-2298.

5. Perroud, H.A.; Rico, M.J.; Alasino, C.M.; Queralt, F.; Mainetti, L.E.; Pezzotto, S.M.; Rozados, V.R.; Scharovsky, O.G. Safety and therapeutic effect of metronomic chemotherapy with cyclophosphamide and celecoxib in advanced breast cancer patients. Future Oncol. 2013, 9, 451-462.

6. Lebeau, B.; Chouaid, C.; Baud, M.; Masanes, M.J.; Febvre, M. Oral second- and third-line lomustine-etoposide-cyclophosphamide chemotherapy for small cell lung cancer. Lung Cancer 2010, 67, 188-193.

7. Hoffman, M.S.; Roberts, W.S.; Bryson, S.C.; Kavanagh, J.J., Jr.; Cavanagh, D.; Lyman, G.H. Treatment of recurrent and metastatic cervical cancer with cis-platin, doxorubicin, and cyclophosphamide. Gynecol. Oncol. 1988, 29, 32-36.

8. Oki, Y.; Ogura, M.; Kato, H.; Kikuchi, A.; Taji, H.; Kagami, Y.; Oshiro, A.; Tsujimura, A.; Yamamoto, K.; Morishima, Y. Phase II study of a salvage regimen using cyclophosphamide, high-dose cytarabine, dexamethasone, etoposide, and rituximab in patients with relapsed or refractory B-cell non-Hodgkin's lymphoma. Cancer Sci. 2008, 99, 179-184.

9. Meistrich, M.L.; Wilson, G.; Brown, B.W.; da Cunha, M.F.; Lipshultz, L.I. Impact of cyclophosphamide on long-term reduction in sperm count in men treated with combination chemotherapy for Ewing and soft tissue sarcomas. Cancer 1992, 70, 2703-2712.

10. Franke, S.I.; Pra, D.; da Silva, J.; Erdtmann, B.; Henriques, J.A. Possible repair action of vitamin $\mathrm{C}$ on DNA damage induced by methyl methanesulfonate, cyclophosphamide, $\mathrm{FeSO} 4$ and $\mathrm{CuSO} 4$ in mouse blood cells in vivo. Mutat. Res. 2005, 583, 75-84.

11. Rehman, M.U.; Tahir, M.; Ali, F.; Qamar, W.; Lateef, A.; Khan, R.; Quaiyoom, A.; Oday, O.H.; Sultana, S. Cyclophosphamide-induced nephrotoxicity, genotoxicity, and damage in kidney genomic DNA of Swiss albino mice: The protective effect of Ellagic acid. Mol. Cell Biochem. 2012, 365, 119-127. 
12. Zhang, Q.H.; Wu, C.F.; Duan, L.; Yang, J.Y. Protective effects of ginsenoside $\operatorname{Rg}(3)$ against cyclophosphamide-induced DNA damage and cell apoptosis in mice. Arch. Toxicol. 2008, 82, 117-123.

13. Fintelmann, V. Modern phytotherapy and its uses in gastrointestinal conditions. Planta Med. 1991, 57, S48-S52.

14. Kamei, J.; Saitoh, A.; Asano, T.; Nakamura, R.; Ichiki, H.; Iiduka, A.; Kubo, M. Pharmacokinetic and pharmacodynamic profiles of the antitussive principles of Glycyrrhizae radix (licorice), a main component of the Kampo preparation Bakumondo-to (Mai-men-dong-tang). Eur. J. Pharmacol. 2005, 507, 163-168.

15. Haggag, E.G.; Abou-Moustafa, M.A.; Boucher, W.; Theoharides, T.C. The effect of a herbal water-extract on histamine release from mast cells and on allergic asthma. J. Herb. Pharmacother. 2003, 3, 41-54.

16. Fukai, T.; Satoh, K.; Nomura, T.; Sakagami, H. Preliminary evaluation of antinephritis and radical scavenging activities of glabridin from Glycyrrhiza glabra. Fitoterapia 2003, 74, 624-629.

17. Yokota, T.; Nishio, H.; Kubota, Y.; Mizoguchi, M. The inhibitory effect of glabridin from licorice extracts on melanogenesis and inflammation. Pigment Cell Res. 1998, 11, 355-361.

18. Inoue, H.; Saito, H.; Koshihara, Y.; Murota, S. Inhibitory effect of glycyrrhetinic acid derivatives on lipoxygenase and prostaglandin synthetase. Chem. Pharm. Bull. (Tokyo) 1986, 34, 897-901.

19. Zhou, S.; Koh, H.L.; Gao, Y.; Gong, Z.Y.; Lee, E.J. Herbal bioactivation: The good, the bad and the ugly. Life Sci. 2004, 74, 935-968.

20. Haraguchi, H.; Ishikawa, H.; Mizutani, K.; Tamura, Y.; Kinoshita, T. Antioxidative and superoxide scavenging activities of retrochalcones in Glycyrrhiza inflata. Bioorg. Med. Chem. 1998, 6, 339-347.

21. Tawata, M.; Aida, K.; Noguchi, T.; Ozaki, Y.; Kume, S.; Sasaki, H.; Chin, M.; Onaya, T. Anti-platelet action of isoliquiritigenin, an aldose reductase inhibitor in licorice. Eur. J. Pharmacol. 1992, 212, 87-92.

22. Tamir, S.; Eizenberg, M.; Somjen, D.; Izrael, S.; Vaya, J. Estrogen-like activity of glabrene and other constituents isolated from licorice root. J. Steroid Biochem. Mol. Biol. 2001, 78, 291-298.

23. Chowdhury, S.A.; Kishino, K.; Satoh, R.; Hashimoto, K.; Kikuchi, H.; Nishikawa, H.; Shirataki, Y.; Sakagami, H.; Tumor-specificity and apoptosis-inducing activity of stilbenes and flavonoids. Anticancer Res. 2005, 25, 2055-2063.

24. Zhou, G.S.; Song, L.J.; Yang, B. Isoliquiritigenin inhibits proliferation and induces apoptosis of U87 human glioma cells in vitro. Mol. Med. Rep. 2013, 7, 531-536.

25. Kim, D.C.; Ramachandran, S.; Baek, S.H.; Kwon, S.H.; Kwon, K.Y.; Cha, S.D.; Bae, I.; Cho, C.H. Induction of growth inhibition and apoptosis in human uterine leiomyoma cells by isoliquiritigenin. Reprod. Sci. 2008, 15, 552-558.

26. Takahashi, T.; Takasuka, N.; Iigo, M.; Baba, M.; Nishino, H.; Tsuda, H.; Okuyama, T. Isoliquiritigenin, a flavonoid from licorice, reduces prostaglandin E2 and nitric oxide, causes apoptosis, and suppresses aberrant crypt foci development. Cancer Sci. 2004, 95, 448-453.

27. Jung, J.I.; Chung, E.; Seon, M.R.; Shin, H.K.; Kim, E.J.; Lim, S.S.; Chung, W.Y.; Park, K.K.; Park, J.H. Isoliquiritigenin (ISL) inhibits ErbB3 signaling in prostate cancer cells. Biofactors 2006, 28, 159-168. 
28. Hsu, Y.L.; Kuo, P.L.; Lin, L.T.; Lin, C.C. Isoliquiritigenin inhibits cell proliferation and induces apoptosis in human hepatoma cells. Planta Med. 2005, 71, 130-134.

29. Wang, K.L.; Hsia, S.M.; Chan, C.J.; Chang, F.Y.; Huang, C.Y.; Bau, D.T.; Wang, P.S. Inhibitory effects of isoliquiritigenin on the migration and invasion of human breast cancer cells. Expert Opin. Ther. Targets 2013, 17, 337-349.

30. Yamazaki, S.; Morita, T.; Endo, H.; Hamamoto, T.; Baba, M.; Joichi, Y.; Kaneko, S.; Okada, Y.; Okuyama, T.; Nishino, H.; et al. Isoliquiritigenin suppresses pulmonary metastasis of mouse renal cell carcinoma. Cancer Lett. 2002, 183, 23-30.

31. Li, D.; Wang, Z.; Chen, H.; Wang, J.; Zheng, Q.; Shang, J.; Li, J. Isoliquiritigenin induces monocytic differentiation of HL-60 cells. Free Radic. Biol. Med. 2009, 46, 731-736.

32. Chen, H.; Zhang, B.; Yao, Y.; Chen, N.; Chen, X.; Tian, H.; Wang, Z.; Zheng, Q. NADPH oxidase-derived reactive oxygen species are involved in the HL-60 cell monocytic differentiation induced by isoliquiritigenin. Molecules 2012, 17, 13424-13438.

33. Chen, X.; Zhang, B.; Yuan, X.; Yang, F.; Liu, J.; Zhao, H.; Liu, L.; Wang, Y.; Wang Z.; Zheng, Q. Isoliquiritigenin-induced differentiation in mouse melanoma B16F0 cell line. Oxid. Med. Cell Longev. 2012, 2012, 534934.

34. Yuan, X.; Zhang, B.; Chen, N.; Chen, X.Y.; Liu, L.L.; Zheng, Q.S.; Wang, Z.P. Isoliquiritigenin treatment induces apoptosis by increasing intracellular ROS levels in HeLa cells. J. Asian Nat. Prod. Res. 2012, 14, 789-798.

35. Yuan, X.; Zhang, B.; Gan, L.; Wang, Z.H.; Yu, B.C.; Liu, L.L.; Zheng, Q.S.; Wang, Z.P. Involvement of the Mitochondrion-dependent and the endoplasmic reticulum stress-signaling pathways in isoliquiritigenin-induced apoptosis of HeLa Cell. Biomed. Environ. Sci. 2013, 26, 268-276.

36. Yuan, X.; Yu, B.; Wang, Y.; Jiang, J.; Liu, L.; Zhao, H.; Qi, W.; Zheng, Q. Involvement of endoplasmic reticulum stress in isoliquiritigenin-induced SKOV-3 cell apoptosis. Recent Pat. Anticancer Drug Discov. 2013, 8, 191-199.

37. Yuan, X.; Li, D.; Chen, H.; Sun, C.; Chen, N.; Wang, Z.; Zheng, Q. Isoliquiritigen Enhances Antitumour Activity of Cyclophosphamid. In Proceedings of the 2010 International Conference on Bioinformatics and Biomedical Technology, Chengdu, China, 18-20 June 2010; pp. 170-173.

38. Kaldor, J.M.; Day, N.E.; Clarke, E.A.; van Leeuwen, F.E.; Henry-Amar, M.; Fiorentino, M.V.; Bell, J.; Pedersen, D.; Band, P.; Assouline, D.; et al. Leukemia following Hodgkin's disease. N. Engl. J. Med. 1990, 322, 7-13.

39. Levine, E.G.; Bloomfield, C.D. Leukemias and myelodysplastic syndromes secondary to drug, radiation, and environmental exposure. Semin. Oncol. 1992, 19, 47-84.

40. Yokoyama, Y.; Futagami, M.; Fukushi, Y.; Sakamoto, T.; Higuchi, T.; Fujii, S.; Sato, S.; Takami, H.; Saito, Y. Secondary acute nonlymphocytic leukemia following successful chemotherapy combining cisplatin, doxorubicin, and cyclophosphamide for stage IV epithelial ovarian cancer. Arch. Gynecol. Obstet. 2000, 263, 206-207.

41. Agarwala, S.; Hemal, A.K.; Seth, A.; Gupta, A.K.; Bhatnagar, V.; Mitra, D.K. Transitional cell carcinoma of the urinary bladder following exposure to cyclophosphamide in childhood. Eur. J. Pediatr. Surg. 2001, 11, 207-210. 
42. Heller, A.; Trifonov, V.; Rubtsov, N.; Sauerbrey, A.; Starke, H.; Loncarevic, I.F.; Claussen, U.; Liehr, T. Complex chromosomal rearrangements in a secondary acute myeloblastic leukemia after chemotherapy in TRAPS. Oncol. Rep. 2003, 10, 1789-1792.

43. Habs, M.R.; Schmahl, D. Prevention of urinary bladder tumors in cyclophosphamide-treated rats by additional medication with the uroprotectors sodium 2-mercaptoethane sulfonate (mesna) and disodium 2,2'-dithio-bis-ethane sulfonate (dimesna). Cancer 1983, 51, 606-609.

44. Jenderny, J.; Walk, R.A.; Hackenberg, U.; Rohrborn, G. Chromosomal abnormalities and sister-chromatid exchange in bone marrow cells of mice and Chinese hamsters after inhalation and intraperitoneal administration. II. Cyclophosphamide. Mutat. Res. 1988, 203, 1-10.

45. Agrawal, R.C.; Kumar, S. Prevention of cyclophosphamide-induced micronucleus formation in mouse bone marrow by indole-3-carbinol. Food Chem. Toxicol. 1998, 36, 975-977.

46. Ozcan, A.; Korkmaz, A.; Oter, S.; Coskun, O. Contribution of flavonoid antioxidants to the preventive effect of mesna in cyclophosphamide-induced cystitis in rats. Arch. Toxicol. 2005, 79, 461-465.

47. Lee, C.K.; Son, S.H.; Park, K.K.; Park, J.H.; Lim, S.S.; Chung, W.Y. Isoliquiritigenin inhibits tumor growth and protects the kidney and liver against chemotherapy-induced toxicity in a mouse xenograft model of colon carcinoma. J. Pharmacol. Sci. 2008, 106, 444-451.

48. Mosmann, T. Rapid colorimetric assay for cellular growth and survival: Application to proliferation and cytotoxicity assays. J. Immunol. Methods 1983, 65, 55-63.

49. Yallapu, M.M.; Maher, D.M.; Sundram, V.; Bell, M.C.; Jaggi, M.; Chauhan, S.C. Curcumin induces chemo/radio-sensitization in ovarian cancer cells and curcumin nanoparticles inhibit ovarian cancer cell growth. J. Ovarian. Res. 2010, doi:10.1186/1757-2215-3-11.

50. Tinwell, H.; Ashby, J. Comparison of acridine orange and Giemsa stains in several mouse bone marrow micronucleus assays-Including a triple dose study. Mutagenesis 1989, 4, 476-481.

51. Wang, Z.; Zheng, Q.; Liu, K.; Li, G.; Zheng, R. Ginsenoside Rh(2) enhances antitumour activity and decreases genotoxic effect of cyclophosphamide. Basic Clin. Pharmacol. Toxicol. 2006, 98, 411-415.

52. Konca, K.; Lankoff, A.; Banasik, A.; Lisowska, H.; Kuszewski, T.; Gozdz, S.; Koza, Z.; Wojcik, A. A cross-platform public domain PC image-analysis program for the comet assay. Mutat. Res. 2003, 534, 15-20.

Sample Availability: Samples of the compounds Isoliquiritigenin and Cyclophosphamide are available from the authors.

(C) 2013 by the authors; licensee MDPI, Basel, Switzerland. This article is an open access article distributed under the terms and conditions of the Creative Commons Attribution license (http://creativecommons.org/licenses/by/3.0/). 